\title{
Article
}

\section{Universal Scale Tipping towards Balance-Applying the MFN Clauses in China-related Investment Arbitration: A New Haven School Reading}

\author{
Yuanchao $\mathrm{Bi}^{*} \&$ Wei Shen ${ }^{* *}$
}

The extension of MFN clauses to dispute settlement under BITs is one of the most controversial areas in investment treaty law. Currently, the area is divided into two streams of case law. The award in Tze Yap Shum v Peru and other recent Chinese investment arbitral awards did not side the Maffezini stream. The question on which stream works the best for China is complicated and essentially a balancing exercise. This article examines the question from a Chinese perspective and adopts the analytical framework of the New Haven School. It identifies the issue of comparability of more preferential treatment as the key criterion in determining the question. It reviews the previous case law and assesses the economic, social and cultural factors shaping the Chinese investment policy. From there, the article seeks to discover if the current law helps fulfil China's policy goals and proposes recommendations accordingly.

Keywords: MFN, Investment Treaty Law, International Law, New Haven School, China, Investment Arbitration

* Trainee Solicitor at Herbert Smith Freehills (Hong Kong office). LL.B. (1 st Class Honours) (CityU HK), LL.M. (LSE). ORCID: https://orcid.org/0000-0003-3565-9369. The author may be contacted at: yuanchao.bi@hsf.com/Address: Herbert Smith Freehills, 23rd Floor Gloucester Tower, 15 Queen's Road Central, Hong Kong Island, HKSAR.

** KoGuan Distinguished Professor of Law, Shanghai Jiao Tong University Law School. LL.B. \& LL.M. (ECUPL), LL.M. (Michigan), LL.M. (Cantab), Ph.D. (LSE). ORCID: https://orcid.org/oooo0002-6935-1365? ?lang=en. The author may be contacted at: shenwei@situ.edu.cn/Address: No. 1954 Huashan Road, Shanghai Jiao Tong University Law School, Shanghai 200030 China. All errors are the authors' own responsibility.

All the websites cited in this article were last visited on August 1, 2020. 


\section{INTRODUCTION}

The myriad things bear shadows and embrace radiance, Are infused with the breath of life to achieve the harmonised trinity of darkness, light and soul. ... Therefore, things may be gained by losing, May be lost by gaining. ${ }^{1}$

The quote above comes from the Tao Te Ching, an ancient Chinese classic by the great Tao philosopher Laozi, which reveals the law of balance and how the universe maintains such balance. Balance is perhaps the theme for the People's Republic of China (PRC) in the area of MFN treatment in international investment law. The extension of MFN clauses to the investor-state dispute settlement (ISDS) under bilateral investment treaties (BITs) is one of the most controversial areas of investment treaty law. A debate that started in the case Maffezini v Spain (Maffezini) $^{2}$ was again activated by both the majority and dissenting opinions in Impregilo SpA v Argentina (Impregilo). ${ }^{3}$ Currently, the area is divided into two streams of case law that are almost impossible to reconcile. The award in Tza Yap Shum v Peru (Tza Yap Shum) and other recent Chinese investment arbitral awards, with very few of them related to China or Chinese BITs, did not side with the Maffezini stream. The question of which stream, or neither of them, works best for China is complicated. China is the second largest economy in the world, but still a developing country. The promotion of economic multilateralism and globalisation would rejuvenate a country that needs both foreign investment coming in and investment of its own capital going abroad. For this process, it must carefully balance the protection both of foreign investors and the host state government.

The New Haven School (NHS) of Jurisprudence uses law to solve social problems and promote human dignity. It provides five interdisciplinary steps of analysis for a particular problem. This article adopts the school's analytical framework to examine MFN clauses from a Chinese perspective, as an attempt to ascertain practical solutions for the issue of extension of MFN clauses as a "social problem" in a Chinese/Asian context. This article reviews previous case law and assesses the economic, social and cultural factors shaping the Chinese investment policy. The article then seeks to discover if current laws, especially those to which 
China and Chinese investors were party, help to fulfil China's policy goals. It contends that, as China has the largest population and market in the world, a desirable legal choice by China could significantly contribute to the promotion of cross-border investment and the improvement of global investment governance. These investments could make positive contributions to human dignity worldwide, as endeavoured by the scholars of the New Haven School.

This paper is composed of six parts including Introduction and Conclusion. Part two will overview the status of MFN under current laws and its application in investment arbitration. A brief introduction of the New Haven School scholarship will be made in Part three. Part four will evaluate the two streams of case law in light of those objectives and discovers that the Maffezini stream may better match China's policies. Part five will recommend the exchange of diplomatic notes clarifying the applicability of MFN clauses as the preferred policy alternative to actualise the ideas of Maffezini, rather than trying to create a Chinese Model BIT or foster investment and nationality planning.

\section{MFN TreatMent AND Its ApPlicability to Disputes Settlement}

\section{A. MFN Treatment}

The International Law Commission (ILC) defines the MFN treatment as "treatment accorded by the granting State to the beneficiary State ... not less favourable than treatment extended by the granting State to a third State." ${ }^{, 5}$ After World War II and the development of non-tariff barriers, the MFN treatment was extended to those measures and played a vital role in the World Trade Organisation (WTO) system. ${ }^{6}$ In light of the political and economic motives behind the granting of the MFN treatment, the New Haven School sees the development as "the product of political and economic compromise., ${ }^{7}$

In the area of investment treaty law, the BITs grant the MFN treatment to the investors or their counterparts. For a long time, the treatment was applied to substantive protection standards such as fair and equitable treatment. ${ }^{8}$ It is rare to see the treatment be applied for the ISDS procedures. The landmark Maffezini case triggered all the controversies. ${ }^{9}$ In this case, the tribunal held that "[i]f a 
third-party treaty contains provisions for the settlement of disputes that are more favourable ... than those in the basic treaty, such provisions may be extended to the beneficiary of the MFN clause as they are fully compatible with the ejusdem generis principle. ${ }^{10}$ In allowing the claimant to bypass an 18-month period of court litigation before commencing arbitration, the tribunal found disputes settlement to be analogous to the administration of justice in the Ambatielos decision. In this case, the Commission of Arbitration held that the latter was essential for the protection of commerce and navigation and, as a result, should qualify as a treatment under the MFN clause. ${ }^{11}$ The MFN clauses are therefore increasingly applied to procedural matters of the ISDS, which are gradually expanded from substantive rights to the protection of procedural rights. ${ }^{12}$

A number of ICSID tribunals followed the Maffezini case but these decisions were heavily criticised. The strongest voice against Maffezini came from Plama Consortium Ltd $v$ Bulgaria (Plama). ${ }^{13}$ The Plama tribunal rejected the claimant's request to activate the Finland-Cyprus BIT through the MFN provision of the Bulgaria-Cyprus BIT in order to commence an ICSID instead of a UNCITRAL ad $h o c$ arbitration. The tribunal argued that an MFN clause could not provide consent, which laid down the very foundation of arbitration. The MFN clause in question would not be extended to the ISDS unless it was seen that the consent was clear and unambiguous or the dispute settlement provision in a third-party BIT was incorporated by reference. ${ }^{14}$ The two streams of case law were formed over the years that seemed almost impossible to reconcile.

The Impregilo award further incited the debate. On the one hand, the majority of the tribunal attempted to partially synthesise the law in the area and ruled that when there was an MFN clause applying to all matters regulated under a BIT, more favourable ISDS clauses in other BITs would be incorporated. ${ }^{15}$ On the other hand, Professor Stern, in his dissenting opinion, contended that the MFN clause should not cover the ISDS, since there was a distinction between rights and fundamental conditions for access to rights, the latter of which an MFN clause was unable to modify. ${ }^{16}$ This ongoing disagreement created a dilemma.

\section{B. Comparability and the More Preferential Treatment Standard}

As to the practice of MFN clause applicable to the ISDS procedure, international arbitral tribunals and the theoretical community divide themselves into two schools 
of thought. Amid different views, both schools focus on the more preferential treatment as the key criterion to the determination of extension.

More preferential treatment means that the implementation of MFN clauses must be based on the treatment enjoyed by the third country, provided that the rights of the third country's rights holders are objectively 'better' than those enjoyed by the rights holders in the basic treaty. ${ }^{17}$

Judging from the jurisprudence, "more preferential treatment" requires that the rights granted by the host state to the investors from different countries be comparable. Here, the investment treatment in the third-party treaty is objectively more preferential than the one in the basic treaty. Only satisfying this comparative superiority can the preferential treatment be granted through the MFN clause in the basic treaty. ${ }^{18}$

If there is a clear difference in the treatments offered in the basic treaty and the third party treaty, there is a clear discrimination against the rights holder under the former. For example, the basic treaty merely provides partial compensation for the expropriation by the host state, while the third party treaty provides for "full, timely and effective" compensation. Obviously, the latter is more favorable to investors. In the EU Imported Banana case at the WTO Dispute Settlement Body in 2007, Colombia and Panama argued that the EU breached the MFN rule under the GATT by imposing tariffs of Euro 176 per ton on bananas imported from these two countries while giving a 77,000-ton duty-free quota to the African-CaribbeanPacific Countries. ${ }^{19}$

The members of the WTO agree to accord MFN status to each other. MFN treatment extends reciprocal bilateral relationships following both GATT and WTO norms of reciprocity and non-discrimination. The non-discriminatory component of the GATT/WTO applies a reciprocally negotiated privilege to all members of the GATT/WTO regardless their status in negotiating the privilege. MFN status is given to an international trade partner to ensure non-discriminatory trade between all partner countries of the WTO. Together with the principle of national treatment, MFN, being the first clause in the GATT, is one of the cornerstones of the WTO trade law. ${ }^{20}$

The purpose of MFN clauses in international treaties is to ensure that legal subjects from foreign countries can compete fairly in the host state without being treated differently. This is why MFN treatment is also termed the non-discriminatory 
treatment. ${ }^{21} \mathrm{MFN}$ is a non-discriminatory trade policy for the purpose of ensuring equal trading among all WTO member nations rather than exclusive trading privileges. Only the existence of more preferential treatment can lead to the application of an MFN clause, which is the consensus and "legal conviction" formed in international law practice. ${ }^{22}$

In Rumeli v Kazakhstan, for example, there is no fair and equitable treatment clause in the Kazakhstan-Turkey BIT. The tribunal supported the Turkish investor Rumeli's invocation of the MFN clause in the Kazakhstan-Turkey BIT to introduce the fair and equitable treatment in Kazakhstan-British BIT and ruled that Kazakhstan violated the fair and equitable treatment to Rumeli, making Rumeli enjoy less favourable treatment than the one enjoyed by the British investors. ${ }^{23}$

Conversely, if the investor cannot prove that there is a more preferential treatment in a third-party treaty than the one in the basic treaty, the tribunal may refuse to support the application of the MFN clause. In Asian Agricultural Products $v$ Sri Lanka, the claimant sought to rely on the MFN clause in the Sri Lanka-UK BIT to introduce the substantive terms in the Sri Lanka-Switzerland BIT. When referring to the MFN clause, the tribunal held the claimant did not explain the substantive treatment in the Sri Lanka-Switzerland BIT, and could not prove that there was a more preferential treatment in the Sri Lanka-Switzerland BIT than the one in the Sri Lanka-UK BIT. ${ }^{24}$ The tribunal therefore objected to the invocation of the MFN clause. In addition, the tribunal further emphasized the burden of proof on the claimant to prove that the treatment specified in the thirdparty treaty is more favorable than the one in the basic treaty. ${ }^{25}$

Similarly, in ADF Group Inc. $v$ US, the investor argued that the obligation to the fair and equitable treatment under the North American Free Trade Agreement (NAFTA) was accompanied by a restrictive interpretation of the limitation to the minimum standard of treatment in customary international law. The Tribunal stated that "any general requirement to accord "fair and equitable treatment" and "full protection and security" must be disciplined by being based upon State practice and judicial or arbitral case law or other sources of customary or general international law. ${ }^{26}$ In the BITs signed by the US, however, there is no such restriction attached to the fair and equitable treatment. Therefore, the investor believed that the fair and equitable treatment in the BITs signed by the US is more preferential than the one in the NAFTA. Nonetheless, the tribunal did not support 
the investor's argument. The tribunal held that although the BITs signed by the US did not provide a restrictive interpretation of fair and equitable treatment, the obligation of fair and equitable treatment was not a separate criterion under the customary international law. The claimant failed to sufficiently prove the existence of a stand-alone standard and thus could not demonstrate that the fair and equitable treatment in the US BITs was more favourable than the fair and equitable treatment under the NAFTA. ${ }^{27}$

Therefore, in terms of the issues raised in this article, it is necessary to determine whether there are more preferential treatments between ISDS procedures under different BITs. At least, three comparisons can be made among, namely, domestic relief of the host country and international arbitration, different international arbitration institutions, and different arbitration rules for the search of more preferential treatment.

A comparison can be made between the domestic remedy and international arbitration. Each of these two disputes resolution procedures has its own operating rules and rationality basis, so that there is no objective comparison standard. The strengths and weaknesses of each can only be reflected in specific cases. Even a 'better' disputes resolution process in a particular case may become much "more inferior" in another case.

Even if a disputes resolution procedure undergoes a subjective assessment, there is a problem on whose subjective standard should be used. Is it by the investor or the host country? Can both parties invoke the BIT that they consider 'better' to choose the best arbitration institution or national court? ${ }^{28}$ In the event of an international investment dispute, the conflict of interests between two parties will inevitably lead to the opposition of the value of judgment. ${ }^{29}$ One party believes that a better disputes resolution method may be precisely what the other party considers worse. Therefore, a subjective assessment cannot solve the problem but rather increases the tension between the parties.

Western scholars widely believe that the domestic legal system in developing countries is imperfect due to the lack of an independent judiciary. The courts of host country will inevitably tend to defend the interests of their governments when they are called to resolve the investment disputes between the governments and foreign investors. Consequently, it is impossible to achieve a fair ruling. Also, resorting to international arbitration is a neutral way of resolving disputes. ${ }^{30}$ 
Therefore, compared with the host state's national courts, international arbitration is not only a 'better,' but also fairer disputes settlement mechanism. ${ }^{31}$ Some scholars directly pointed out that the parties choose international arbitration exactly because of its neutrality and impartiality. ${ }^{32}$ In Maffezini, Spain believed that even if the MFN clause could be applied, Maffezini would need to prove resorting to the ICSID arbitration was more preferential than the domestic litigation in Spain. ${ }^{33}$ In that regard, the tribunal simply responded that, conventionally, investors have always believed that international arbitration is more conducive to protecting their rights than the courts in the host state. This view of the arbitral tribunal is considered to be the "inherent belief" that most international arbitral tribunals have in adjudicating similar cases. ${ }^{34}$

The arguments of both tribunals and scholars in favour of international arbitration is valid if contemplating these arguments together with the purpose of the BITs. As such, the subjective evaluation by foreign investors may be taken into account. The host state's view is less meaningful in this regard.

What is more, some scholars opine that the quality of arbitration is determined by arbitrators. ${ }^{35}$ If this argument is established, then who can guarantee that the arbitrators will always be impartial? Perhaps because of this, the fairness of arbitration is considered to be conditional. For example, some scholars believe that the fairness and finality of international arbitration can be respected only if the following two conditions are satisfied: first, arbitrators make no mistake; and second, the subject matter of the dispute is so small that it can be ignored. ${ }^{36}$ Professor Clive M. Shimitthoff points out that, compared with the litigation, the biggest advantage of arbitration is "no appeal mechanism" to correct the arbitrators' mistakes. Other benefits of arbitration are in doubt.

\section{China's Foreign Investment Policy: A New Haven School Perspective}

China is the world's second largest economy but a developing country simultaneously. It is also a capital importer and exporter. As a result, the goals of China's investment policies and the interested parties behind them are not easily reconcilable. In this part, applying the steps and partially analysing the NHS, this article briefly reviews the 
history and practice of the PRC's investment policy. It then identifies the country's goals, stakeholders and influencing factors.

\section{A. New Haven School}

The NHS of Jurisprudence was nurtured by Professors Myres S. McDougal and Harold D Lasswell at Yale Law School. ${ }^{38}$ In their eyes, law is an authoritative and controlling decision-making process ${ }^{39}$ that adopts a policy-oriented ${ }^{40}$ or processbased $^{41}$ approach to fully analyse international law-making processes. The school embraces a type of socio-legal realism by looking to the complex and dynamic social processes or settings ${ }^{42}$ that combines international law with practice, ${ }^{43}$ and promotes human dignity and world order. ${ }^{44}$ The NHS, through the lens of normative communities, maps these processes using cultural anthropology as a conceptual technique in line with the perspective of legal pluralism. ${ }^{45}$ It considers the participants of the decision-making process, their perspectives, situations and bases of power, strategies and outcomes.

In the process of analysis, "comprehensiveness" is highlighted. ${ }^{46}$ The school provides a way of organising thought and action, with seven factors to organise thoughts and actions: intelligence, promotion, prescription, invocation, application, termination, and appraisal. ${ }^{47}$ It strives to create a future world with a public order of human dignity through eight values: power, enlightenment, wealth, wellbeing, skill, affection, respect and rectitude. ${ }^{48}$ This article will pay due attention to China's situation by reference to the NHS because According to Professor Wiessner, the NHS addresses a legal issue through a five-step discipline of tasks that will seek:

(1) $[T]$ he ... problem the law has to address; (2) to review the conflicting interests or claims; (3) to analyse the past legal responses in light of the factors that produced them; (4) to predict future such decisions; and (5) to assess the past legal responses, invent alternatives and recommend solutions better in line with a good order, ... a public order of human dignity. ${ }^{49}$

\section{B. Chinese Inward and Outward Investment Policy: History and Practice}

With the advent of the communist system, the former regime's numerous foreign investments were gradually nationalised or expropriated. Between 1949 and 1978, 
there was no significant inward or outward investment. ${ }^{50}$

From 1978 to 1991, in the aftermath of the social and economic damage inflicted by the Cultural Revolution, the Chinese government implemented the "opening up and reform" policy. It legislated a series of domestic laws ${ }^{51}$ and signed BITs between Western developed partners and China's traditional partners. ${ }^{52}$ The reform process accelerated in 1992 when Deng Xiaoping completed his "Southern Tour" to Shenzhen and decided to establish a socialist market economy, which led to a further round of legislation, revisions and another batch of BITs. ${ }^{53}$ In 1993, China also joined the ICSID Convention. ${ }^{54}$ During this period, considerable foreign direct investment (FDI) entered China. ${ }^{55}$

Before the late 1990s, most of the Chinese BITs notably contained a narrowly worded ISDS clause. ${ }^{56}$ A good example is Article 8(3) of the China-Peru BIT, a relevant clause in Tza Yap Shum:

If a dispute involving the amount of compensation for expropriation cannot be settled within six months after resort to negotiations ..., it may be submitted ... to the international arbitration of the ICSID. Any disputes concerning other matters ... may be submitted to the Centre if the parties to the disputes so agree. ${ }^{, 57}$

Seventy of these "first generation" BITs are still in force, which are the main focus of this article's discussion. ${ }^{58}$

China was admitted to the WTO in 2001. To comply with the WTO standards, China conducted a massive revision of its laws and regulations. It also entered into another 40 BITs, with more comprehensive and liberal ISDS clauses included and renegotiated some previous BITs with Western European countries. At the same time, as the "Go Globally" policy was implemented to encourage investors to invest abroad, China then witnessed another surge of FDI and ODI. ${ }^{59}$ By 2018, China had concluded 145 BITs $^{60}$ and it had the second-largest FDI inflow and third-largest outflow state across the globe. ${ }^{61}$ Moreover, since 2015, the Chinese government has started the "One Belt One Road" Initiative (BRI) to facilitate investment and trade across Asia, Europe and Africa. ${ }^{62}$

\section{Policy-based Assessment}

Based on the policy practice given above, and by applying the New Haven School's analytical approach, this article identifies the objectives of China's investment 
policy: to safeguard state sovereignty; to continue attracting FDI; to achieve economic prosperity by further promoting ODI and to play a greater role in global affairs. The realist assumption of international law is that states behave in their own interests which depend on China's internal political system, relative affluence and external pressures, among others. ${ }^{63}$ Nevertheless, the Chinese government, Chinese investors, foreign investors and their home states are the stakeholders in the BIT-making process and their interests may be in conflict with each other. These goals play out against a background of economic, social, cultural and historical factors that shape the whole picture. China has to cautiously balance all of these considerations to choose the most appropriate legal position.

\section{Sovereignty}

Due to historical and social factors, safeguarding national sovereignty is a policy objective of Chinese investment law. ${ }^{64}$ As Professor An Chen points out:

[E]ver since the failure of the 1840s Opium War, the Chinese people have experienced ... loss of sovereignty and State insults, including having no jurisdiction over disputes involving foreign affairs within the territory of China and being forced to accept the consular jurisdiction. $^{65}$

Chinese people suffered from consular jurisdiction as well as foreign investments. For instance, China was forced to allow the Japanese investors to set up industries within the Chinese (Qing) Empire after the First Sino-Japanese War. ${ }^{66}$ Against this background, sovereignty is a shorthand for control and autonomy in favour of a strong and secure state, instead of robust international law or institutions. As international law as endogenous to state interests then is a product of state self-interest, ${ }^{67}$ it is used as a tool to help China achieve optimal outcomes in any bilateral, regional or multilateral game. ${ }^{68}$

As state interest is coincident with the "preferences of the state's political leadership," ${ }^{, 69}$ China's investment policy reflects this sensitivity to sovereignty to the present day. With the founding of the 'new' China in 1949, the Chinese people and government gained a sense of sovereignty and independence. They wanted to assert that they were no longer controlled by Western powers. In those first years, and perhaps as a symbol of independence and control, the Chinese government nationalised or expropriated a considerable number of foreign businesses and 
investments.

The narrowly worded dispute and the ISDS clauses in approximately 70 Chinese old-generation BITs reflect strong feelings against surrendering jurisdiction to a non-Chinese body. In addition to the ISDS clauses, "equality and mutual benefits" are referred to between the state parties, ${ }^{70}$ which perhaps reflects the sense of inferiority Chinese people had in the past. This previous emotional reaction still resonates in today's investment policy, which has an objective of protecting sovereignty. $^{71}$ In recent years, however, asserting sovereignty is a less crucial concern as China has grown and gained economic and political strength in the international sphere. This is reflected in China's incorporation of comprehensive ISDS clauses in its new generation of BITs. Accordingly, it is advisable to take a qualified approach when examining the role of sovereignty in the policy-making process of Chinese BITs.

\section{Economic Prosperity - From FDI to ODI}

Another objective in Chinese investment policy is to achieve economic prosperity. President Xi Jinping proclaimed in the report of the Communist Party's 19th National Congress that the CCP would build a prosperous society and ultimately realise the great rejuvenation of the Chinese nation. To achieve this economic goal, President Xi said that China would "adopt policies to promote high-standard liberalisation and facilitation of trade and investment," "protect the legitimate rights and interests of foreign investors" and "develop new ways of making outbound investments.", 72

For China to continue its economic growth through 40 years of economic reforms, it needed to attract a significant amount of FDI and, therefore, signed many BITs. China's success in attracting FDI also rested in its improvements in protecting foreign investors. When the economy slowed and FDIs were no longer contributing as significantly as in the past, China encouraged its nationals to go abroad so that further economic growth could take place. This led to China's "Go Globally" strategy and its modernised comprehensive ISDS clauses in newgeneration BITs. These clauses enabled Chinese investors to defend their rights and interests before international tribunals. Some measures to afford better procedural and substantive protection in BITs were needed because China's predominant interest had previously been to attract FDI. It now left Chinese 
investors unprotected in previous BITs with narrow ISDS clauses had to be constructed so they would not be abused by foreign investors and backfire. Hence, there are dual objectives in China's investment policy that require a careful balancing act to encourage more investment abroad.

\section{International Image}

Last, but not least, the goals of Chinese investment policy must have an international angle. Professor Guiguo Wang criticises the Tza Yap Shum tribunal for unjustifiably adopting a broad interpretation of the narrowly worded ISDS clause. He suggests "[s] uch a statement itself was obviously biased and discriminatory." "73 In another piece of writing, he advocates that China must make more contributions to ensure other countries to be a responsible member of the international community. ${ }^{74}$

The authors concur with his view. Although China still sees itself as a developing country and needs further investment to become fully modernised, it is significantly wealthier and stronger than it was 40 years ago. China can now go beyond focusing on its own development and make more contributions to the international community. China does not arbitrarily expropriate private property and foreign investments. The adoption of comprehensive ISDS clauses in BITs addresses these concerns and responds to the "distrust or ideological unconformity" seen in the profiling of the Tza Yap Shum tribunal.

China's strong desire to expand ODI also needs to be tempered by concerns about its international image during negotiations and enforcement of mutual investment obligations. Yet, China does not want to appear to be a bully before other nations, especially those developing countries. Here, the MFN clauses might be taken as a good example. Article II of the Sino-US Treaty of Wanghia, concluded after China's defeat in the Opium War, states that "[C]itizens of the United States ... will pay the duties of import and export prescribed in the Tariff... They shall, in no case, be subject to other or higher duties than are ... required of the people of any other nation whatever." 75 The benefits granted to the US were completely one-sided, while China should not inflict the same harm to other countries.

Having reviewed its investment policy practice, this article shows that China's main policy goals are safeguarding national sovereignty, increasing economic prosperity through FDI and ODI and enhancing international image, against a 
background influenced by underlying socio-historical, economic and political factors. Throughout this assessment, it can be seen that the stakeholders are the Chinese government, Chinese investors, foreign investors and foreign governments, with their respective interests.

\section{Investment Arbitration Cases: Past and Future}

People are still debating whether or not the consent to arbitration as ratione voluntatis is equally important with ratione personae, ratione materiae and ratione temporis. ${ }^{76}$ When the international law-making, as the New Haven School stressed, is a complex, decentralized and diverse process, multiple norm-generating communities should be taken into account. ${ }^{77}$ Needless to say, investment arbitral tribunals as an elite group of lawyers are on-the-ground micro-decisionmakers which in turn shape the key component in a bottom-up law-making process. These micro-decisions are reflective of legal consciousness on both an individual and institutional level. ${ }^{78}$ Tribunals, typically classified as non-state actors as well as international institutions, ${ }^{79}$ have emerged on the transnational law-making scene and gained their importance at least in the sphere of international investment, while the state's hegemony in international lawmaking wanes. Caution, however, must be paid to the black box nature of these tribunals, with club-like secrecy, in their award-making processes which win themselves both normative status, as transnational actors (opposed to classic state diplomats) in energizing international investment law and norms, ${ }^{80}$ and legitimacy crisis in more recent times.

\section{A. Does the Case Law Guarantee National Sovereignty?}

The Plama stream of case law appears to be more favourable to the sovereignty concern. With a close examination of its content, however, perhaps what is contended by the stream is not what China needs. First, the reasoning of the stream is likely to be flawed. As mentioned in Introduction, Plama insisted on the clear and unambiguous consent and incorporation by reference. ${ }^{81}$

The arbitral tribunal in Berschader v. Russia,${ }^{82}$ a progeny of Plama, recognised and further developed the principle of incorporation by reference, though it expressed doubts on the clear and unambiguous consent requirement. The tribunal 
developed the test to show that "an MFN provision in a BIT will only incorporate by reference an arbitration clause from another BIT where the terms of the original BIT clearly and unambiguously so provide or where it can otherwise be clearly inferred." ${ }^{, 83}$ To support its conclusion that there was no such incorporation, the tribunal noted that "the principle of state sovereignty ... was of fundamental importance to the Soviet Union." ${ }^{84}$ The Tza Yap Shum tribunal also raised similar communist-regime concerns, albeit in a rather biased and discriminatory manner, as mentioned above.

These decisions are seemingly friendly to states that hold strong reservations to investment arbitration on the grounds of state sovereignty. Future tribunals can adopt this test and easily admit the sovereignty issue and its related policies as evidence against the extension. Nonetheless, those decisions may not withstand closer scrutiny. The restrictive interpretive approach and the unambiguous requirement by Plama have long been a point of heavy criticism. The restrictive approach of the Berschader tribunal was problematic; on a more fundamental level, it is questionable whether or not the commercial arbitration requirement should be equally applicable in investor-state arbitration.

As observed by Schill, Plama was influenced by private law; by drawing analogies to private contracts and commercial arbitration, it dismissed the relevance of public international law. ${ }^{85}$ Acconci points it out that "a[n] [MFN] treatment clause is not only a treaty clause, but also a source of international obligations other than those included in the basic treaty." only inconsistent with the MFN principles, but also contradicts the contemporary trends of investment treaty law. ${ }^{87}$ Professor Van Harten echoes this view. Warning against the tribunals' expanding the general consent of states under the principle of party autonomy, he reasons that private law principles should be irrelevant when the treaty is ambiguous, because the general consent is a sovereign, not a private, act. ${ }^{88}$ Professor Van Harten's critiques point to one extreme of over-expanding the consent, while the Plama tribunal seems to go to the other extreme. Using a principle that was probably ungrounded, the tribunal strangled the general consent to the clear and unambiguous consent.

Arising from the Plama decision, Berschader and Tza Yap Shum decisions are also problematic. The Berschader tribunal built its arguments on and further developed Plama's requirements. Although it reserved its opinion to a restrictive 
interpretation approach, it still relied on the clear and unambiguous incorporation by a reference test. What is more, a reading of the whole text of Plama appears to show that its core reasoning was based on this clear and unambiguous requirement, which may not be separated from incorporation by reference. As a consequence, reliance on the latter could not excuse the Berschader tribunal, yet it depends on both. The reasons offered by the Tza Yap Shum tribunal are also questionable. Although the tribunal adopted a restrictive interpretation of the dispute settlement clause and accordingly rejected the extension, it oddly interpreted the phrase "involving expropriation" in a very broad manner, without giving due regard to Professor An Chen's authoritative expert opinion. ${ }^{89}$ As Shen comments, "[d]ue to the lack of inherent consistency, the award does not form part of the development of substantive principles of international investment arbitration. ${ }^{, 90}$ In light of these internal flaws, China should be cautious when it attempts to use these awards to defend its sovereignty considerations, though the decisions are not precedents. ${ }^{91}$

Apart from the problems of the Plama stream, the stream may not be the appropriate legal choice for China because the adoption of the comprehensive ISDS clauses implies that the Chinese government has less concern for the loss of sovereignty and changed its policy focus. As Gallagher and Shan point out, "[t]he willingness to incorporate a more standard dispute-settlement provision represents a move by China in favour of international arbitration within the last ten years. ${ }^{, 92}$ Schill further suggests that this change of scope in the new generation of Chinese BITs reflects a fundamental change in the PRC's foreign economic policy, deviating from previous Marxist ideology on international law by accepting a beneficial bargain in favour of foreign investment. ${ }^{93}$ Chandler even argues that allowing indirect investment and expansions in new Chinese BITs entails China's implicit consent to broad MFN interpretation. ${ }^{94}$ The authors suggest that a state bear the MFN obligation with its own treaties in mind. When the state adopts a more favourable practice in certain areas in its subsequent BITs, it is aware that the MFN treatment will operate to initialise the importation, provided that the MFN clause does cover that practice. In practice, however, it may not matter if the investors still use the MFN provision, since "China might agree to arbitrate a dispute in any event." ${ }^{95}$

Case law seems to support this "implied consent" approach. In Maffezini, one of the reasons favouring importation was that the dispute settlement clause of the 
Argentina-Spain BIT was a policy compromise between the states. Argentina's later abandonment of exhaustion of local remedies in its subsequent BITs further showed direct access to arbitration which was a more favourable treatment. ${ }^{96}$ Since Spain believed in the benefits of direct access during its negotiation with Argentina, it could not say that such access was not more favourable and refuse to grant it. $^{97}$

However, a potentially powerful objection can be launched against the above position. The fact that a state allows a more favourable treatment in a subsequent BIT may not be automatically equated with a permission to make the new treatment cover the previous treaties. What Spain did in Maffezini illustrates this. Although Spain clearly favoured direct access in the Argentina-Spain BIT negotiation and had allowed direct access in many other BITs, it still objected to extending the jurisdiction when the Argentine investor requested the importation. The speculation may be that, a real danger that Spain would have to undertake monetary compensation and other remedies in a case it lost in the arbitration may have played a central role in Spain's decision-making process. Adopting investorfriendlier policies does not mean that a state will not object in certain cases and whenever it has to pay.

If that is the case, the same logic should equally apply to China. China did expand the scope of its ISDS provisions in the new BITs. However, this should not mean China automatically agrees to extend such arrangements to its previous treaties. Unwilling to incur fiscal liabilities, the Chinese government can invoke the narrowly worded ISDS clauses, like Article 8(3) of the China-Peru BIT, to never 'agree' to submit to arbitration the disputes arising out of the old-generation BITs. The recent BIT practice by China also signifies its attitude to such implied consent. Article 139(2) (MFN clause) of the China-New Zealand Free Trade Agreement provides that "[f]or greater certainty, the obligation in this Article does not encompass a requirement to extend to investors of the other Party dispute resolution procedures other than those set out in this Chapter." ${ }^{\text {,98 }}$ China's trilateral investment treaty with Japan and Korea also takes a negative but firm stance on this issue. ${ }^{99}$

On the basis of the above analysis, it may be submitted that the implied consent approach may be unsound. Further, it believes the Plama stream sovereigntyfriendly case law does not need to play a decisive role in China's future legal 
choices. In spite of the failure of the "implied consent," a significant policy shift does exist in China. China is now a responsible player of the international community. It should refuse to submit to arbitration even though it could. In fact, China should consciously agree if such requests are raised by investors. Instead of losing sovereignty, this gesture would reinforce the perception of China's strength as a sovereign nation. Therefore, China need not fear losing sovereignty and the Plama stream thus may not serve China's policy goals.

\section{B. Does the Case Law Enable China to Further Attract FDI and Encourage ODI?}

The cases in the Maffezini stream would serve as a better model for China's policy objectives of continuing the influx of FDI while also fostering ODI by Chinese investors. It seems to especially bolster China's keen desire to invest abroad because the Maffezini stream emphasises the benefit of investment arbitration for investors. The Maffezini tribunal stated that "dispute settlement arrangements are inextricably related to the protection of foreign investors." ${ }^{, 100}$ The tribunal in Gas Natural SDG v Argentina found independent arbitration is the "most crucial element" because it offers "assurances that disputes [of investors] ... would not be subject to the perceived hazards of delays and political pressures of adjudication in national courts." ${ }^{101}$ On that basis, the tribunal held that the MFN clause should in principle be applicable to dispute resolution. ${ }^{102}$

Under the "Go Globally" strategy and the BRI, more Chinese investors, both private and state owned, invest around the world. On the one hand, the narrow ISDS provisions in the old-generation BITs substantially disallow investors' claims. Moreover, the current manner in which a state expropriates an investment has become more subtle and people can rarely find a direct expropriation case, as Eliasson rightly observes. ${ }^{103}$ The narrow definition of dispute in the 70 or so oldgeneration BITs only covers the compensation issue after a direct expropriation, which effectively renders the ISDS provisions a "toothless tiger." On the other hand, Chinese investors have encountered the difficulties caused by these narrow ISDS clauses. The Chinese claimants in the cases of Tza Yap Shum, Sanum ${ }^{104}$ and $B U C G,{ }^{105}$ all requested a broader interpretation beyond the quantum of compensation, ${ }^{106}$ which have already counted for half of the Chinese claims under the ICSID regime by July $2020 .{ }^{107}$ This indicates that the academic concerns on the meaningless ISDS clauses are real concrete threats to Chinese investors, not mere 
speculation. With a clear emphasis on investors' rights to arbitration, the Maffezini stream may empower investors and allow Chinese policymakers to activate the MFN clauses for comprehensive dispute resolution.

Apparently, challenges to the Maffezini stream remain. The common criticism from adherents to the Plama stream is that there is no precedent for the Maffezini finding. ${ }^{108}$ However, this article discounts that argument. First, public international law cases including arbitral awards are not binding precedents, ${ }^{109}$ despite the persuasive nature of the judgements. Moreover, unprecedented situations will always arise as the world continues to change. If an answer is needed for a new circumstance, similar solutions will be examined even if they are not identical. The Maffezini tribunal made analogies to a solution offered by the Commission of Arbitration, which is a "similar situation." The function of the MFN clauses in the two cases was very close, respectively.

The authors contend that whether or not an MFN clause is applicable to the ISDS clauses ought not to be a question of precedent, but rather a question of an MFN clause being extended. This requires returning to the essential question of what an MFN treatment actually means. If its essence is inclusive of dispute resolution, then there should be no reason to exclude it. For this issue, the ILC, in its draft articles, offered no more than the definitions and emphasised that an MFN clause could only extend the treatment of the subject matter it covered. ${ }^{110}$ The UNCTAD, however, provides some clues. It discovers that the scope of the early MFN clauses was very broad, and applied to "a wide range of issues such as rights, privileges, immunities and exceptions," with respect to trade, commerce and navigation. ${ }^{111}$ Likely, the wording is adequately wide to cover dispute resolution, even though it was not explicit to the issue. Therefore, "[u]nless the BIT limits the scope of the MFN clause, the pledge of equal treatment in an MFN clause applies broadly to all aspects of the legal regime applicable to foreign investors, including the dispute settlement mechanism." 112 It makes a BIT a "toothed tiger." If this submission is reasonable, then it is fair to say the lack of precedent argument does not stand.

An even more fundamental problem may stand up to challenge. The Plama tribunal questioned the generality of the statement of inextricability of dispute resolution to investor protection. It relied on Ian Sinclair's worries over the "risk that the placing of undue emphasis on the "object and purpose" of a treaty will 
encourage teleological methods of interpretation [which], in some of its more extreme forms, will even deny the relevance of the intentions of the parties." ${ }^{, 13}$ Professor Guiguo Wang duly agrees and suggests a strict compliance with Article 31 and 32 of the Vienna Convention on the Law of Treaties when interpreting an MFN clause, as does the alternative policy recommendation in his New Haven School writings. ${ }^{114}$

There is no need to deny that such danger exists. In this regard, various tribunals from the Maffezini stream relied on the object and purpose of the treaty and, from there, adopted an "investor-friendly" approach. However, it is worth reiterating that the danger is on over-reliance, rather than mere reliance. Compared with Plama's negative view against extension, it is questionable whether the Maffezini stream excessively relied on the object and purpose. After a closer look at the arbitral decisions, the submission here is that the truth may not be as Plama argued. Taking Siemens $A G v$ Argentina $^{115}$ as an example, the tribunal found that the intention of the BIT was to create favourable conditions for investment and to stimulate private initiative, ${ }^{116}$ which, on its face, was a pro-investor interpretation. Yet, people might not know that the very brief preamble of the Argentina-Germany BIT made no reference to the host state's right to regulate. ${ }^{117}$ If the wording of a preamble can be used as a sole criterion, some BITs will be then classified as pro-investor and others as pro-host state. According to Gallagher and Shan, most Chinese BITs, for instance, contain pro-host state elements, including to "contribute to the prosperity of both contracting parties" and "equality and mutual benefits." If If the preamble before the Siemens tribunal had possessed a prohost-state expression, the outcome could have been different. When the wording of an MFN clause is unclear, and it is valid to resort to a preamble to ascertain the object and purpose, it might not be wrong for a tribunal of a "pro-investor" BIT to rely on the text in the preamble. A tribunal should not be blamed because it has a pro-investor preamble before it. If so, then more fundamental challenge from Plama may not withstand a closer examination and the Maffezini stream may be seen as valuable for China's future investment policy.

In conclusion, the Maffezini stream may help China accomplish its main investment policy objectives, because the sovereignty anxiety raised by the Plama stream is not as significant as it was in the past and the Maffezini stream could enhance Chinese investors' rights to submit to arbitration. 


\section{Policy Alternatives and Recommendations}

The ultimate nature of the NHS is a functional critique of international law in terms of social ends. ${ }^{119}$ Having assessed the current legal responses to and analysis of the MFN treatment's extension to the ISDS issue, this article now comes up with the possible policy alternatives for China's BIT regime. There are three options available, namely: a Chinese Model BIT; investment and nationality planning; and the exchange of diplomatic notes or letters clarifying the contracting parties' clear position on the scope of MFN clauses. These options try to reconcile top-down international law-making's conceptual promise of organic inclusivity with the bottom-up club-like exclusivity functioned by investment tribunals. ${ }^{120}$ In Lasswell's terms, it is a process of reconfigurating macro-law and micro-law. ${ }^{121}$ Examining each option, the authors believe that the exchange of diplomatic documents may be a more desirable choice for China's old-generation BITs in the next five to ten years.

\section{A. Chinese Model BIT}

Apart from over 3000 BITs worldwide, there are over a dozen of states that have a Model BIT, which is a "pre-drafted BIT template formulated by the state offering a draft for negotiation with the counterparty for a new BIT." ${ }^{\text {,22 }}$ While a Model BIT is arguably to promote efficiency and consistency, the real reason for the signatory states to enter into a BIT based on the Model BIT is the asymmetry and inequality in bargaining power between the investors and host state who may be more eager to attract inbound FDI. ${ }^{123}$ In some cases, a new Model BIT may be crafted to ride the new investment treaty waves, ${ }^{124}$ by splitting the bill between investor protection and state regulation, ${ }^{125}$ or indicating a new policy move departing from its current BIT regime. ${ }^{126}$

Professor Guiguo Wang advocates the idea of a Model BIT. His proposal is based on the NHS's view that the infrastructures of international economic organisations are shaped by the contributions of major powers and that BITs are important components of such infrastructures. Accordingly, he proposes to make "a publicly announced and more detailed and comprehensive draft," though he realises the PRC government should have some internal models. ${ }^{127}$ "The Chinese Model BIT would serve not only as a basis for future negotiations, but also as 
a signal of the government's policy intentions that would, in turn, offer more predictability and transparency of state party counterparts and foreign investors alike. ${ }^{, 28}$ Before making the draft, thorough research should be conducted. ${ }^{129}$ In this way, China could contribute to the healthy development of investment treaty law and be seen as a responsible member of the international society. ${ }^{130}$ However, it is not clear if this is going to cast any more light on China's investment strategy which is very much contextual and distinguishable depending on a given investment relationship. There may be more consensus on the legal framework. Yet, the prospects of its application would still depend on China's policy objectives that vary in time and space. Nonetheless, in terms of image-building regarding China's contribution to the international rules-based order, this is an important signal.

This proposal for a Model BIT has a merit because it may be a good option for developing not only Chinese investment treaty law, but also MFN treatment and MFN clauses specifically. Even Professor Wang acknowledges that the Chinese government may use internal models. It is doubtful how much more a published Model BIT would contribute. Such a Model BIT may not properly respond to the hardship currently being experienced by Chinese investors, either. As explained above, Chinese investors are currently constrained by the narrowly worded dispute and ISDS provisions in approximately 70 old-generation BITs and have requested broader interpretation for better rights protection. They need a legal solution that, immediately or in the near future, enable them to activate the dispute resolution procedures based on those BITs. This is what a Model BIT cannot do for them. Some could argue that the Model BIT shows the policy stance of the Chinese government, which can help the future tribunals interpret existing Chinese BITs. The effect certainly exists. However, the authors suggest there be the same problem with the "implied consent" approach discussed above. The state can, nevertheless, refuse to let the new policy thinking "date back" to the BITs previous to the Model BIT. Consequently, the Model BIT option may not be the most effective and efficient one, compared with other proposals.

\section{B. Investment and Nationality Planning}

This approach is mainly supported by Eliasson ${ }^{131}$ and echoed by Schill. ${ }^{132} \mathrm{He}$ states that "one option might be to structure the investment so that it is channelled 
through a company incorporated in a jurisdiction with which the state, in which the investment is made, has entered into a satisfactory investment treaty." ${ }^{133}$ In this course, a Chinese investor needs only to let the holding company initiate the claim. This sort of planning and structuring has the advantage of low costs and, therefore may be a desirable choice. ${ }^{134}$ Eliasson draws his support from such cases like Tokios Tokelés $v$ Ukraine (Tokios Tokelés) ${ }^{135}$ and Saluka Investments BV (The Netherlands) $v$ Czech. He observes that the tribunals tend to recognise the nationality of the investor. ${ }^{136}$

It is submitted that the effectiveness and actual benefits brought by investment and nationality planning should be questioned. Actually operating this method, the harms incurred may more severe than the benefits, because the differences between tribunals in different cases, and even the different members of the same tribunal in one case, are often far from being reconciled. The Tokios Tokelés case referred to by Eliasson demonstrates the problem. In this case, the majority of the tribunal held that the ICSID Convention left the parties with broad discretion to determine corporate nationality. Nothing in Article 25 of the ICSID Convention excludes entities controlled by the respondent's nationals. Tribunals should enforce consensual criteria by the parties unless doing so would allow the Convention to be used for unintended purposes. ${ }^{137}$ The dissent ruled opposite; it argued that the matter was not to be left to the parties just because Article 25 does not address it. The purpose of the Convention relates to the origin of capital, and the economic reality is closely related to the international determination of investors. ${ }^{138}$

Unfortunately, Tokios Tokelés is not the only decision with a sharp division of opinions concerning the issue. ${ }^{139}$ Eventually, investment and nationality planning will be another treaty interpretation problem, as the MFN clauses have already been. Whenever there is a treaty interpretation issue, the fate of investment and nationality planning becomes uncertain. In these situations, the parties will inevitably engage in lengthy debates at the hearing. Very often the members of the arbitral tribunal cannot reach consensus on a single version of interpretation, which prolongs the deliberation process. This consumes significant costs, time and energy. Hence, uncertainty is a serious problem for investment and nationality planning. One may say that if good planning is done before a dispute arises, the investor will not encounter any jurisdictional issues and the resources expended in the dispute's prevention process can be substantially lower. As long as the 
claimant has a complex corporate structure, however, it is more likely than not that the respondent state will raise the nationality issue as a ground of objections to the jurisdiction of the arbitral tribunal. Even Eliasson admits that investors should treat the previous arbitral awards with great caution as they are not precedents and it is uncertain that future tribunals will follow them. ${ }^{140}$ As a result, investment and nationality planning might not be the best alternative. The situation will only be aggravated if an uncertain issue is met with an uncertain solution.

\section{Exchange of Diplomatic Notes}

As far as China's contracting practices are concerned, its newly signed international investment treaties have explicitly ruled out the possibility of piggybacking on the MFN clause for the application of a more favorable ISDS clause. However, the problem remains if the scope of the MFN clause is not clearly defined in the old BITs. To overcome this potential danger, the best solution would be for China to exchange diplomatic notes with countries which have the old-generation BITs.

The exchange of notes or letters has the nature of an international treaty between the contracting parties concerning the matters of mutual relations. States express their consent to be bound by an exchange of letters or notes. The characteristic of this procedure is that the signatures appear not on both letters, but on two separate letters or notes. The agreement lies in the exchange of letters or notes. It is easy for governments to conclude treaties without going through complicated, ordinary treaty rectification procedures. In particular, an exchange of notes or letters usually does not need to be approved first by the legislature of the contracting parties, leading to its convenience and efficiency. ${ }^{141}$ In a bilateral treaty, letters or notes may also be exchanged to indicate that all necessary domestic procedures have been completed. The exchange of notes is technically resorted to its speedy procedure or the avoidance of local legislative process or approval. $^{142}$

This has already set a precedent for practice globally. For example, after the decision on jurisdiction in Siemens in 2004, Argentina exchanged a letter with the Panamanian government for the purpose of clarifying the scope of MFN clause in the BIT signed by the two countries in 1996. The parties were clarified to have no intention to apply the MFN clause to the investment dispute settlement process.

For the next five to ten years, China can conduct small-scale negotiations solely 
on the MFN issue, whose best outcome would be that the parties agree to extend the MFN treatment to dispute resolution. Such exchange through diplomatic channels was practised by states in the past. "Argentina and Panama ... exchanged diplomatic notes after the jurisdictional decision in Siemens $v$ Argentina in order to clarify that the MFN clause in their investment treaty did not apply to dispute resolution." ${ }^{143}$

This approach is beneficial because it provides a quicker solution than a model BIT and a more certain outcome than investment and nationality planning. As Kurtz points out, cited by Acconci, "the solution to the appropriate parameters of the MFN clause will not necessarily be solved through future treaty amendment as is perhaps inevitable given the large universe of existing BITs." ${ }^{144}$ This is especially true for China, as it has one of the largest number of BITs in the world and, so far, renegotiated very few of the old-generation BITs. ${ }^{145}$ Exchanging diplomatic notes can take a substantially shorter time than negotiating an amendment. Once the parties agree with letters exchanged, it immediately removes the obstacles for Chinese investors to apply for the extension. Even if the parties cannot agree, the worst scenario for China would be to issue a joint clarification denying the applicability of the MFN clause, which would create a certainty for investors allowing them to resort to other options.

It may be that many developing countries, counterparts in the old BITs, will not agree to the extension because the claims would overburden them. China and its counterparts are very likely to amend the whole BITs in the future, given their outdated nature. These would probably incorporate comprehensive ISDS clauses. In that way, the contracting parties will sooner or later have to address noncompensation disputes. This awareness could ease the anxiety of the counterpart nations. Moreover, the reciprocal nature of BITs would also enable the investors from their counterparts to extend the MFN treatment in their disputes.

\section{Conclusion}

In this article, the authors would recommend that China welcome the extension of MFN clauses to the ISDS clauses in the BITs. We have adopted the analytical framework of the NHS to explore the issue. The Chinese investment policy and 
law have three major goals - sovereignty, economic prosperity through FDI and ODI, and strong international image, while also acknowledging underlying political, economic, historical and social factors. Notably, the sovereign consideration plays a less critical role in the decision-making process in more recent times. Weighing the objectives, this article evaluates the past legal responses in this area: the Maffezini and Plama streams of case law. In spite of the advantage of sovereign protection, the Plama stream should not be preferred because of its internal drawbacks and the limited imperative to tightly grab state sovereignty in contemporary China. In contrast, the ideas and logic of the Maffezini stream appear to correspond with the economic side of China's investment policy. In the short-term, the implementation of Maffezini can be in the form of a diplomatic exchange for the coming five to ten years, which is preferable to the Model BIT and investment and nationality planning, due to their obvious weaknesses.

China has to consider many balances including its sovereignty and flow of investments; FDI and ODI; its own development path and international responsibilities; and its past, present and future. As Tao Te Ching says, "one aspect increases, while another decreases.” [故物或损之而益, 或益之而损] With hope, perhaps "[China's] dual role of a capital-importing and capital-exporting country would arguably lead to a particularly balanced outcome in the negotiation of international investment agreements ... because China has to find a trade-off." ${ }^{146}$

Although this article could not conduct a thorough inquiry in accordance with the NHS methodology, but just only offer a short term plan, it should be a valuable starting point for the application of the NHS Jurisprudence specifically to the issue of MFN extension to the ISDS in BITs. Unlike international law, international law-making, ${ }^{147}$ based on the NHS, is both a top-down and bottom-up social processes, involving an inherently grounded balance of "community expectations" with "enough effective power to be put into controlling practice." 148 The way to implement the policy recommendations of this article, apart from being "a matter of choice," ${ }^{149}$ might fuel discussions for "alternative futures" ${ }^{150}$ in this field. A potential long-term solution for China should also be a preferable path of inquiry. 


\section{REFERENCES}

1. Laozi, Tao Te Ching Ch. 42 (Vintage Books, 1972).

2. Maffezini v. Spain, ICSID Case No. ARB/97/7, Decision on Objection to Jurisdiction (Jan. 25, 2000).

3. Impregilo S.p.A. v. Argentina, ICSID Case No. ARB/07/17, Award (June 21, 2011).

4. Señor Tza Yap Shum v. Peru, ICSID Case No. ARB/07/6, Decision on Jurisdiction and Competence (June 19, 2011).

5. ILC Draft Articles on Most-Favoured-Nation Clauses with Commentaries, [1978] 2:2 Y.B. Int'1 L. Comm'n 74. For details, see Guiguo Wang, International Investment Law: A Chinese Perspective 335 (2015).

6. WANG, id. at 338 .

7. Id. at 335 .

8. Pope \& Talbot Inc. v. Canada, IIC 192, Interim Award, (Arbitral Trib., 2000), available at https://www.italaw.com/sites/default/files/case-documents/ita0674.pdf.

9. Supra note 2 , at 958.

10. Id. at 921.

11. Id. at $9 \uparrow 17-18$.

12. As of June 30, 2016, there have been at least 23 arbitral tribunals in related cases, and 21 arbitral awards have been published, including 13 rulings in favour of MFN clauses and 8 against such rulings. See Arthur Ma, Most Favoured Nation Treatment, June 2020, available at https://thelawreviews.co.uk/edition/the-investment-treaty-arbitration-reviewedition-5/1227618/most-favoured-nation-treatment.

13. Plama Consortium Ltd. v Bulgaria, ICSID Case No. ARB/03/24, Decision on Jurisdiction (Feb. 8, 2005).

14. Id. at $93-65$.

15. For the majority opinion, see supra note $3, \boldsymbol{q} 27$. (majority opinion).

16. For the dissenting opinion, see $i d$. at 25.

17. S. Page \& P. Kleen, Special and Differential Treatment of Developing Countries in the World Trade Organization, in Global Development Studies (Swedish Ministry for Foreign Affairs ed., 2005), available at https://www.odi.org/sites/odi.org.uk/files/odiassets/publications-opinion-files/3320.pdf.

18. G. Kofler, Most-Favoured-Nation Treatment in Direct Taxation: Does EC Law Provide For Community MFN in Bilateral Double Taxation Treaties?, 5 Hous. Bus. \& TAx L. J. 4-7 (2005).

19. European Communities-Regime for the Importation of Bananas, WTO Doc. WT/DS361, $\mathrm{WT} / \mathrm{DS} 364$, at 938.

20. S. Rubin, Most-Favoured-Nation Treatment and The Multilateral Trade Negotiations: A Quiet Revolution, 6:2 Int'L TRADE L. J. 222 (1981). 
21. G. Egli, Don't Get Bit: Addressing ICSID's Inconsistent Application of Most-FavouredNation Clauses to Dispute Resolution Provisions, 34:4 Pepp. L. Rev. 1045 (2007).

22. ILC Draft Articles on Most-Favoured-Nation Clauses, supra note 5.

23. Rumeli Telekom AS v. Republic of Kazakhstan, ICSID Case No. ARB/05/16, Award (July 29, 2008) at $\uparrow 575$.

24. Asian Agricultural Products Limited v Republic of Sri Lanka, ICSID Case No. ARB/87/3, Final Award, (June 27, 1990) at 94 . (stating that: "Accordingly, it is not proven that the Sri Lanka/Switzerland Treaty contains rules more favourable than those provided for under the Sri Lanka/U.K. Treaty, and hence, Article 3 of the latter Treaty cannot be justifiably invoked in the present case.")

25. Id. at 956.

26. ADF Group Inc. v United States of America, ICSID Case No. ARB(AF)/00/1, Award (Jan. 9, 2003) at 184.

27. Id. at 194.

28. R. Teitelbaum, Who's Afraid of Maffezini? Recent Developments in the Interpretation of the Most Favoured Nation Clause, 22 J. InT'L Arb. 226 (2005).

29. UnCtad, Most-Favoured-Nation Treatment 31-2 (2010), U.N. Doc. UnCTAD/ DIAE/IA/2010/1, U.N. Sales No. 10.II.D.19 (2010).

30. S. Schill, International Investment Law and Comparative Public Law 53 (2010).

31. For example, there were 145 rulings made since the establishment of ICSID, and only 11 rulings were revoked in whole or in part by subsequent special committees, fully demonstrating the fairness of the ICSID ruling.

32. W. Park, The Specificity of International Arbitration: The Case for FAA Reform, 36 VAND. J. TRANSNAT'L L. 1256 (2003).

33. Supra note 2, at 95.

34. J. Kurtz, The MFN Standard and Foreign Investment-An Uneasy Fit?, J. WorLd Inv. \& TRADE 880 (2004).

35. S. Bond, The International Arbitrator: From the Perspective of ICC International Court of Arbitration, 12:1 Nw. J. INT'L L. \& Bus. 1 (1991).

36. W. Knull \& N. Rubins, Betting the Farm on International Arbitration: Is It Time to Offer an Appeal Option? 11:4 Am. Rev. InT'L Arb. 531 (2000).

37. Id.

38. For a historical account of the New Haven School, see generally, W. Reisman et al., The New Haven School: A Brief Introduction, 32 Yale J. InT'L L. 575 (2007).

39. Id. at 576.

40. E. Suzuki, The New Haven School of International Law: An Invitation to A Policy-Oriented Jurisprudence, 1 YALE J. INT'L L. (1974).

41. P. Berman, A Pluralist Approach to International Law, 32 Yale J. InT'L L. 301 (2007).

42. W. Reisman, The Democratization of Contemporary International Law-Making, in 
Developments of International Law in Treaty Making 26 (R. Wolfrum \& V. Roben eds., 2005). See also M. McDougal \& H. Lasswell, The Identification and Appraisal of Diverse Systems of Public Order, 53 Am. J. InT'L. L. 7 (1959); M. McDougal et al., The World Constitutive Process, Part 1, 19 J. Legal Educ. 281-3 (1967).

43. J. Levit, Bottom-up International Lawmaking: Reflection on the New Haven School of International Law, 32 YALE J. INT'L L. 420 (2007).

44. M. Land, Reflections on the New Haven School, 58 N.Y. L. Sch. L. Rev. 919 (2013/4).

45. P. Berman, From International Law to Law and Globalization, 43 Colum. J. Transnat'L L. 485 (2005).

46. W. Reisman et al., supra note 38, at 577.

47. Id. at 580 .

48. Id.

49. S. Wiessner, The New Haven School of Jurisprudence: A Universal Toolkit for Understanding and Shaping the Law, 18:1 Asia PAC. L. Rev. 48 (2010).

50. N. Gallagher \& W. Shan, Chinese Investment Treaties: Policies and Practice $\mathbf{q} 1.07$ $\& 1.20$ (2009).

51. See, e.g., The Law of Sino-Foreign Equity Joint Ventures (1990 Revision), available at http://www.lehmanlaw.com/resource-centre/laws-and-regulations/foreign-investment/ sino-foreign-equity-joint-venture-law-1990.html.

52. T. Cohen \& D. Schneiderman, The Political Economy of Chinese Bilateral Investment Treaty Policy, 5:1 ChINESE J. CoMP. L. 127 (2017).

53. Supra note 50, at 9 ๆ 1.12-1.13.

54. ICSID, About ICSID - Member States - Database of ICSID Member States, available at https://icsid.worldbank.org/en/Pages/about/Database-of-Member-States.aspx.

55. Supra note 50, at $9 \uparrow 1.13,1.21-1.22$.

56. S. Schill, Tearing Down the Great Wall: The New Generation Investment Treaties of the People's Republic of China, 15 CARdozo J. InT'L \& Comp. L. 91 (2007).

57. Agreement Concerning the Encouragement and Reciprocal Protection of Investments, China-Peru, art. 8(3), June 9, 1994, 1901 U.N.T.S. 257.

58. B. Horrigan et al., China-related Investment Arbitrations: Three Recent Developments, HSF Arbitration Notes (July 17, 2017), available at https://hsfnotes.com/arbitration/ 2017/07/17/china-related-investment-arbitrations-three-recent-developments.

59. Supra note 50, at 9 甲 1.14-1.16, 1.23-1.24.

60. UNCTAD Investment Policy Hub, International Investment Agreements NavigatorChina-China Bilateral Investment Treaties (BITs), available at https://investmentpolicy. unctad.org/international-investment-agreements/countries/42/china?type $=$ bits.

61. UnCTAD, World Investment Report 2018-Investment and New Industrial Policies, at 4-5, U.N. Doc. UNCTAD/WIR/2018, U.N. Sales No. E.18.II.D.4 (2018).

62. National Development and Reform Commission (Ministry of Foreign Affairs and 
Ministry of Commerce of the People's Republic of China), Vision and Actions on Jointly Building Silk Road Economic Belt and 21st-Century Maritime Silk Road (Mar. 2015), available at https://www.fmprc.gov.cn/mfa_eng/zxxx_662805/t1249618.shtml.

63. M. Byers, Custom, Power, and the Power of Rules, 17 Мich. J. InT'L L. 142 (1995).

64. M. Carrai, Sovereignty in China: A Genealogy of a Concept since 1840 (2019).

65. A. Chen, Should the Four Great Safeguards in Sino-Foreign BITs be Hastily Dismantled?: Comments on Provisions concerning Dispute Settlement in Model US and Canadian BITs, 7 J. World Inv. \& TRADE 901 (2006).

66. Treaty of Shimonoseki, 1895, Japan-China, art. 6, May 8, 1895, available at https://china. usc.edu/treaty-shimonoseki-1895.

67. See generally J. Goldsmith \& E. Posner, The Limits of International Law (1st ed. 2005).

68. This appears to match the so-called rational choice theory advocated by the nationalist claim of international law. See id. at 13.

69. Id. at 6 .

70. Supra note 50, at 1.97.

71. T. Hall, Emotional Diplomacy: Official Emotion on the International Stage ch. 2 (2015).

72. Xi Jinping Address at the 19th National Congress of the Communist Party of China: Secure a Decisive Victory in Building a Moderately Prosperous Society in All Respects and Strive for the Great Success of Socialism with Chinese Characteristics for a New Era (Oct. 18, 2017), available at http://www.chinadaily.com.cn/interface/flipboard/ 1142846/2017-11-06/cd_34188086.html.

73. Guiguo Wang, International Investment Law: An Appraisal from the Perspective of the New Haven School of International Law, 18:1 Asia PAC. L. Rev. 30 (2010).

74. G. Wang, China's Practice in International Investment Law: From Participation to Leadership in the World Economy, 34 YaLE J. InT'L L. 586 (2009).

75. Treaty of Peace, Amity, and Commerce (The Treaty of Wanghia), 1844, U.S.-The Chinese Empire (China), July 3, 1844.

76. S. Schill, Maffezini v Plama: Reflections on the Jurisprudential Schism in the Application of Most-Favored Nation Clauses to Matters of Dispute Settlement, in BuILDING InTERnATIONAL Investment Law: The First 50 Years of ICSID 261-2 (M. Kinnear et al. eds., 2015).

77. See generally J. D'Aspremont, Epistemic Forces in International Law Foundation Doctrines and Techniques of International Legal Argumentation (2015).

78. Supra note 45 , at $542 \& 546$.

79. T. Cheng, Making International Law Without Agreeing What It Is, 10:1 Wash. UnIV. Glob. Stud. L. Rev. 1 (2011).

80. H. Koh, Transnational Legal Process, 75 NeB. L. Rev. 183 (1996).

81. Supra note 13, at 63-5.

82. Vladimir Berschader \& Moïse Berschader v. The Russian Federation, SCC Case No. 
080/2004, Award (Apr. 21, 2006).

83. $I d$. at 62 .

84. Id. at 68 .

85. Supra note 76 , at $257-8$.

86. P. Acconci, Most-Favoured-Nation Treatment, in The Oxford HANDBOoK of InTERnATIONAL InVESTMENT LAw 402 (P. Muchlinski et al. eds., 2008).

87. Id.

88. G. Van Harten, Investment Treaty Arbitration and Public Law 125-6 \& 128-30 (2007).

89. Supra note 4 , at 151.

90. W. Shen, The Good, the Bad or the Ugly? A Critique of the Decision on Jurisdiction and Competence in Tza Yap Shum v The Republic of Peru, 10 ChINESE J. InT'L L. 94 (2011).

91. Convention on the Settlement of Investment Disputes between States and Nationals of Other States, art. 53, Oct. 14, 1966, 575 U.N.T.S. 159 (hereinafter ICSID Convention).

92. Supra note 50, at 98.112.

93. Supra note 56 , at $76-7 \& 115$.

94. A. Chandler, BITs, MFN Treatment and the PRC: The Impact of China's Ever-Evolving Bilateral Investment Treaty Practice, 43:3 InT'L Law. 1310 (2009).

95. Supra note 50, at 98.113.

96. Supra note 2, at 21.

97. Id.

98. Free Trade Agreement between the Government of New Zealand and the Government of the People's Republic of China, New Zealand-China, art. 139(2), Apr. 7, 2008, 2590 U.N.T.S. 101.

99. N. Gallagher, China's BITs and Arbitration Practice: Progress and Problems, in CHINA and International Investment Law: Twenty Years of ICSID Membership 203 (J. Su \& W. Shan eds., 2015).

100. Supra note 2, at 20.

101. Gas Natural SDG, S.A. v. Argentina, ICSID Case No. ARB/03/10, Decision of the Tribunal on Preliminary Questions on Jurisdiction, 19 (June 17, 2005). See also, RosInvestCo UK Ltd. v. Russia, SCC Case No. V079/2005, Final Award, 79 (Sept. 12, 2010); Suez and InterAguas v. Argentina, ICSID Case No. ARB/03/17, Decision on Jurisdiction, 33 (May 16, 2006); Suez, Sociedad General de Aguas de Barcelona, S.A. \& Vivendi Universal, S.A. v. Argentine Republic, ICSID Case No. ARB/03/19, Decision on Jurisdiction, 33 (Aug. 3, 2006).

102. Gas Natural SDG, S.A. v. Argentina, ICSID Case No. ARB/03/10, Decision of the Tribunal on Preliminary Questions on Jurisdiction, 19 (June 17, 2005), at 49.

103. N. Eliasson, Chinese Investment Treaties: A Procedural Perspective, in Foreign Investment and Dispute Resolution Law and Practice in Asia 93 (V. Bath \& L. Nottage eds., 2011). 
104. Sanum Investments Ltd. v. Laos, [2016] SGCA 57 at 9-10.

105. Beijing Urban Construction Group Co. Ltd. v Yemen, ICSID Case No. ARB/14/30, Decision on Jurisdiction (May 31, 2017).

106. D. Pathirana, Making an Arbitration Claim under Chinese BITs: Some Inferences from Recent ISDS Cases, 5 CHINESE J. CoMP. L. 426-7 (2017).

107. ICSID - Cases, available at https://icsid.worldbank.org/en/Pages/cases/AdvancedSearch. aspx.

108. Supra note 13 , at 67-9.

109. ICSID Convention, art 53; Statute of the International Court of Justice, art. 59, Oct. 24, 1945, 59 Stat. 1055, U.N.T.S. No. 993.

110. Supra note 5, at 27.

111. Supra note 29 , at 9.

112. S. Vesel, Clearing a Path Through a Tangled Jurisprudence: Most-Favored-Nation Clauses and Dispute Settlement Provisions in Bilateral Investment Treaties, 32:1 YALE J. InT'L L. 184 (2007).

113. Supra note 13 , at 62.

114. Supra note 5, at 381-2.

115. Siemens A.G. v. Argentina, ICSID Case No. ARB/02/8, Decision on Jurisdiction (Aug. $3,2004)$.

116. Id. at 31 .

117. Bilateral Investment Treaty between Germany and Argentina, Argentina-Germany, Apr. 9, 1991, available at https://investmentpolicy.unctad.org/international-investmentagreements/treaty-files/92/download.

118. Supra note 50, at 91.98 .

119. H. Koh, Is There a "New” New Haven School of International Law, 32:2 YALE J. INT'L L. 562 (2007).

120. M. Koskenniemi, From Apology to Utopia: The Structure of International Legal Argument 597 (2009).

121. W. Nagan \& C. Hammer, Communications Theory and World Public Order: The Anthropomorphic, Jurisprudential Foundations of International Human Rights, 47(3) VA. J. INT'L L. 726-804 (2007).

122. J. Nam, Model BIT: An Ideal Prototype or A Tool for Efficient Breach?, 48 GEO. J. INT'L L. 1277 (2017).

123. Id. at 1275 .

124. K. Duggal \& L. de Ven, The 2019 Netherlands Model BIT: Riding the New Investment Treaty Waves, 35:3 ARB. INT'L 347 (2019), available at https://doi.org/10.1093/arbint/ aiz013.

125. T. Cummins et al., Going Dutch: Netherlands Model BIT "Splits the Bill Between Investor Protection and State Regulation, AsHuRst, Dec. 20, 2018, available at https://www. 
ashurst.com/en/news-and-insights/legal-updates/going-dutch-netherlands-model-bitsplits-the-bill-between-investor-protection-and-state-regulation/.

126. K. Modani, Why India's Model Bilateral Investment Treaty Need A Thorough Relook, Bus. Standard, Dec. 31, 2018, available at https://www.business-standard.com/article/ economy-policy/why-india-s-model-bilateral-investment-treaty-needs-a-thoroughrelook-118123100150_1.html.

127. Supra note 73 , at 586.

128. Id.

129. Id. at 587.

130. Id. at 586 .

131. N. Eliasson, Investor-State Arbitration and Chinese Investors: Recent Developments in Light of the Decision on Jurisdiction in the Case Tza Yap Shum $v$ The Republic of Peru, 2(2) Contemp. Asia Arb. J. 364-6 (2009). See also supra note 103, at 102-3.

132. Supra note 76 , at 265.

133. Supra note 131, at 364.

134. Id. at 364-5.

135. Tokios Tokelés v Ukraine, ICSID Case No ARB/02/18, Decision on Jurisdiction of 29 April 2004.

136. Supra note 131, at 366.

137. Supra note 135 , at $9-10 \& 16$. (majority opinion)

138. $I d$. at 14. (dissenting opinion)

139. TSA Spectrum de Argentina S.A. v Argentina, ICSID Case No. ARB/05/5, Award (Dec. 19, 2008).

140. Supra note 103, at 98 .

141. National Grid PLC v. Argentina, Decision on Jurisdiction, at 71 (Arbitral Trib., June 20, 2006), available at https://www.italaw.com/sites/default/files/case-documents/ ita0553.pdf.

142. Vienna Convention on the Law of Treaties, art. 13, Jan. 27, 1980, 1155 U.N.T.S. 331.

143. M. Kinnear et al., (eds) Building International Investment Law - The First 50 Years OF ICSID 61 (2016).

144. Supra note 86 , at 404.

145. Supra note 62.

146. Supra note 56, at 115.

147. The New Haven School distinguishes international law from international law-making, keenly focusing on law-making as opposed to law. See W. Reisman, International Lawmaking: A Process of Communication, in The Harold D. Lasswell Memorial Lecture at the American Society of International Law (Apr. 24, 1981), available at https://digitalcommons.law.yale.edu/cgi/viewcontent.cgi? article $=1719 \&$ context $=$ fss papers. 
148. M. McDougal, International Law and the Future, 50 Miss. L. J. 281 (1979).

149. P. Spiro, Disaggregating US Interests in International Law, 67 L. \& ContemP. ProbS. 201 (2004).

150. R. Cover, The Supreme Court, 1982 Term-Forward: Nomos and Narrative, 97 Harv. L. REv. 4 (1983). 